\title{
Pengembangan Aplikasi Android Pada UKM Basket Universitas Diponegoro
}

\author{
Adrian Putranda Rispurwadi ${ }^{1)}$, R. Rizal Isnanto ${ }^{2)}$, Rinta Kridalukmana ${ }^{2)}$ \\ Jurusan Sistem Komputer, Fakultas Teknik, Universitas Diponegoro \\ Jl. Prof. Sudharto, Tembalang, Semarang, Indonesia
}

\begin{abstract}
Until now, Diponegoro University has become one of the most favored State University for High School students to proceed their study. So far, there hasn't been any information system for basketball student organization in Diponegoro University such as mobile device application that provides information, field location, and reminder for the basketball practice. Based on this concern, an application for the information system must be made on Android Operation System.

Design of mobile information system for basketball student organization in Diponegoro University based android, a client server application created by using theJava, PHP, jQuery and MySQL for database. The intake of latitude and longitude coordinate will utilize the GPS feature on the mobile device and will be displayed on Google Maps API. JSON will collect the data of schedules into the mobile device, continued to recieve dialog alert and broadcast reciever for the alarm feature.

The result of this design is realization of a application that able to search location of a basketball field based on android system, equipped with features that can help user to find the field and alarm to remind them of practice time. This design is also used to introduce android application developers using the Global Positioning System functions for user navigation.
\end{abstract}

Keywords: Android, Java, PHP, jQuery, MySQL, Location Based Service, Latitude, Longitude, GPS, Google Maps APIs, JSON, Alert Dialog, dan Broadcast Receiver

\section{PENDAhUluan}

\section{A. Latar Belakang}

$\mathrm{K}$ esibukan atau rutinitas yang ada di masyarakat Indonesia pada umumnya sering menimbulkan berbagai kejenuhan, untuk itu perlunya diupayakan suatu alternatif yang dapat menghilangkan kejenuhan tersebut. Salah satu alternatif untuk menghilangkan rasa jenuh tersebut adalah dengan cara berolahraga.

Basket merupakan olahraga permainan yang menggunakan bola besar, dimainkan dengan tangan. Bola boleh dioper (dilempar ke teman), boleh dipantulkan ke lantai (ditempat atau sambil berjalan) dan tujuannya adalah memasukkan bola ke basket lawan. Permainan dilakukan oleh dua regu masingmasing terdiri dari 5 pemain, setiap regu berusaha memasukkan bola ke keranjang lawan dan menjaga (mencegah) keranjangnya sendiri kemasukan sedikit mungkin. Dalam menghadapi persaingan kompetisi atau pertandingan, penguasaan teknik permainan sangat penting terutama dalam penguasaan teknik dasar permainan bola basket. Penguasaan teknik dasar yang baik harus benar-benar dikuasai oleh seorang pemain bola basket. Pencapaian prestasi tidak hanya ditentukan oleh kondisi fisik saja akan tetapi lebih ditentukan oleh kemampuan teknik bermain. Pada permainan bola basket, untuk mendapatkan gerakan efektif dan efisien perlu didasarkan pada penguasaan teknik dasar yang baik

Namun pada saat ini belum adanya aplikasi pada perangkat bergerak yang memanfaatkan teknologi untuk membuat sistem informasi Unit Kegiatan Mahasiswa (UKM) Basket, sehingga masih banyak mahasiswa baru yang mengalami kesulitan dalam mengetahui informasi tentang UKM Basket Undip.

Dengan alasan tersebut penulis memiliki ide untuk membuat suatu aplikasi yang dapat digunakan pada perangkat bergerak berbasis android untuk sistem informasi UKM basket Universitas Diponegoro..

\section{B. Tujuan}

Tujuan utama pada penelitian ini adalah untuk membangun sistem informasi dan aplikasi UKM Basket Undip yang dapat digunakan untuk memberikan informasi tentang registrasi, jadwal, event, data pemain dan alarm pengingat jam latihan.

\section{Batasan Masalah}

Pada penelitian tugas akhir ini agar tidak meluas, maka penulis perlu melakukan pembatasan masalah yaitu sebagai berikut.

1. Sistem yang dirancang dapat melihat informasi tentang UKM Basket Universitas Diponegoro.

2. Lingkup kerja sistem adalah pada mahasiswa Universitas Diponegoro.

3. Sistem informasi dijalankan pada sistem Mobile Android.

4. Sistem Informasi dan aplikasi UKM Basket Undip menggunakan bahasa pemrograman PHP, HTML, basisdata MySQL, dan basisdata SQLite.

5. Hasil sistem informasi UKM Basket Undip akan disimulasikan pada web sederhana dan Android.

\section{LANDASAN TEORI}

A. Android

Android (sistem operasi) - OS Android - banyak dikatakan sebuah robot hijau karena logo yang 
dikenalkan oleh raksasa mesin pencari yaitu google.inc. Android adalah system operasi untuk telepon seluler yang berbasis Linux. Android Menyediakan Platform terbuka bagi para pengembang untuk menciptakan aplikasi mereka sendiri untuk digunakan oleh bermacam peranti bergerak. Awalnya, Google Inc. membeli Android Inc, pendatang baru yang membuat perangkat lunak untuk ponsel. Kemudian untuk mengembangkan Android, dibentuklah Open Handset Alliance, konsorsium dari 34 perusahaan perangkat keras, perangkat lunak, dan telekomunikasi, ternasuk Google, HTC, Intel, Motorola, Qualcomm, T-Mobile, dan Nvidia

Di dunia ini terdapat dua jenis distributor sistem operasi Android. Pertama yang mendapat dukungan penuh dari Google atau Google Mail Services (GMS) dan kedua adalah yang benar-benar bebas distribusinya tanpa dukungan langsung Google atau dikenal sebagai Open Handset Distribution (OHD). ${ }^{[17]}$

\section{B. Location Based Service (LBS)}

Location Based Service (LBS) merupakan layanan informasi berbasis lokasi yang dapat diakses menggunakan perangkat bergerak melalui jaringan Internet dan seluler serta memanfaatkan kemampuan penunjuk lokasi pada piranti mobile. Dengan kata lain LBS merupakan kemampuan sebuah perangkat bergerak dengan bantuan GPS untuk menunjukkan suatu letak lokasi.

Location Based Service (LBS) memberikan kemungkinan komunikasi dan interaksi dua arah. Oleh karena itu pengguna memberitahu penyedia layanan untuk mendapatkan informasi yang dia butuhkan, dengan referensi posisi pengguna tersebut. Layanan berbasis lokasi dapat digambarkan sebagai suatu layanan yang berada pada pertemuan tiga teknologi yaitu Geographic Information System, Internet Service. ${ }^{[1]}$

\section{Google Maps API}

Google Map merupakan layanan aplikasi peta online yang disediakan oleh Google secara gratis. Layanan peta Google Map secara resmi dapat diakses melalui situs http://maps.Google.com. Pada situs tersebut dapat dilihat informasi geografis pada hampir semua permukaan di bumi kecuali daerah kutub utara dan selatan. ${ }^{[8]}$ Layanan ini di buat sangat interaktif, karena di dalamnya peta dapat digeser sesuai keinginan pengguna, mengubah level zoom, serta mengubah tampilan jenis peta. Google Map mempunyai banyak fasilitas yang dapat di pergunakan misalnya pencarian lokasi dengan memasukkan kata kunci, kata kunci yang dimaksud seperti nama tempat, kota atau jalan, fasilitas lainnya yaitu perhitungan rute perjalanan dari satu tempat, ke tempat lain. ${ }^{[7]}$

\section{Global Positioning System (GPS)}

Global Positioning System atau biasa disebut dengan GPS, merupakan merupakan sistem navigasi dengan menggunakan teknologi satelit yang dapat menerima sinyal dari satelit. Sistem ini menggunakan 24 satelit yang mengirimkan sinyal gelombang mikro ke bumi. Satelit-satelit itu milik Departemen Pertahanan (Departemen of Defense) Amerika Serikat yang pertama kali diperkenalkan mulai tahun 1978 dan pada tahun 1994 Sinyal ini diterima oleh alat penerima (receiver) di permukaan, dimana GPS receiver ini akan mengumpulkan informasi dari satelit GPS.

Berdasarkan pemakaiannya GPS dapat

dikategorikan sebagai berikut:

1 Lokasi

Digunakan untuk menentukan dimana lokasi suatu titik dipermukaan bumi berada.

2 Navigasi

Membantu mencari lokasi suatu titik di bumi

3 Tracking

Membantu untuk memonitoring pergerakan obyek, Membantu memetakan posisi tertentu, dan perhitungan jaringan terdekat. ${ }^{[10]}$

\section{E. Javascript Object Notation (JSON)}

JSON (JavaScript Object Notation) adalah format pertukaran data yang ringan, mudah dibaca dan ditulis oleh manusia, serta mudah diterjemahkan dan dibuat (generate) oleh komputer. Format ini dibuat berdasarkan bagian dari Bahasa Pemprograman JavaScript, Standar ECMA-262 Edisi ke-3 Desember 1999. JSON merupakan format teks yang tidak bergantung pada bahasa pemprograman apapun karena menggunakan gaya bahasa yang umum digunakan oleh programmer keluarga $\mathrm{C}$ termasuk C, C++, C\#, Java, JavaScript, Perl, Python dan lain-lain. Oleh karena sifat-sifat tersebut, menjadikan JSON ideal sebagai bahasa pertukarandata. $^{[12]}$

\section{F. MySQL}

MySQL adalah sebuah perangkat lunak sistem manajemen basis dataSQL (Database Management System) atau DBMS yang multithread, multi-user, dengan sekitar 6 juta instalasi di seluruh dunia. MySQL AB membuat MySQL tersedia sebagai perangkat lunak gratis dibawah lisensi GNU (General Public License), tetapi mereka juga menjual dibawah lisensi komersial untuk kasus-kasus dimana penggunaannya tidak cocok dengan penggunaan GPL. ${ }^{[18]}$

\section{G. PHP}

PHP (Prepocessor Hypertext) adalah salah satu bahasa paling populer untuk server-side scripting yang bersifat sumber terbuka. PHP dapat bekerja lintas platform, tujuan utama bahasa ini didesain untuk membangkitkan halaman web yang dinamis. ${ }^{[14]}$

PHP pertama kali ditemukan oleh seorang pengembang perangkat lunak bernama Rasmus Lerdrof pada tahun 1995. Ide awal PHP adalah ketika Rasmus ingin mengetahui jumlah pengunjung yang membaca resume onlinenya. Script yang dikembangkan baru dapat melakukan dua pekerjaan, yakni merekam informasi pengunjung dan menampilkan jumlah pengunjung dari suatu website. Kemudian, dari situ 
banyak orang di milis mendiskusikan script buatan Rasmus Lerdrof, hingga akhirnya Rasmus mulai membuat sebuah alat/script, bernama Personal Home Page (PHP). ${ }^{[18]}$

\section{Eclipse}

Eclipse adalah sebuah software IDE (Integrated Development Environment) open source yang dibuat oleh perusahaan Eclipse Foundation, untuk mengembangkan perangkat lunak juga dapat dijalankan di semua platform (platform-independent). Pengembangan terbuka terdiri dari extensible, kerangka kerja dan alat runtimes untuk membangun, menyebarkan dan mengelola perangkat lunak diseluruh siklus hidup. ${ }^{[6]}$

\section{J. Unit Kegiatan Mahasiswa Basket}

Unit Kegiatan Mahasiswa Basket atau biasa disebut UKM Basket merupakan salah satu UKM olahraga yang ada di Universitas . UKM Basket ini sebagai wadah dan sarana kegiatan bagi para mahasiswa yang menyukai olahraga basket untuk menyalurkan bakat dan hobi mereka. Selain berlatih dan bermain basket, para anggota juga belajar berorganisasi. UKM Basket memiliki pelatih memiliki lisensi kepelatihan. Sarana yang dimilliki UKM Basket pun lengkap dan memadai seperti lapangan, ring, dan bola basket. Semua fasilitas hanya dapat digunakan oleh mereka yang telah mendaftar sebagai anggota UKM Basket. Masa keanggotaan yang berlaku di UKM Basket adalah seumur hidup. ${ }^{[16]}$

\section{K. Unified Modeling Language (UML)}

Unified Modeling Language (UML) merupakan bahasa grafis untuk menvisualisasikan, menspesifikasikan, membangun, dan melakukan dokumentasi sistem perangkat lunak. UML menunjukkan standar penulisan cetak biru sistem, mencakup hal-hal konseptual seperti proses bisnis dan fungsi sistem seperti kelas dalam bahasa pemrograman khusus, skema basisdata, dan komponen daur ulang. ${ }^{[20]}$

\section{K. Entity Relationship Diagram (ERD)}

Entity Relationship Diagram adalah alat pemodelan data utama dan akan membantu mengorganisasikan data dalam suatu proyek ke dalam entitas-entitas dan menentukan hubungan antar-entitas. Proses memungkinkan analisis menghasilkan struktur basisdata yang baik sehingga data dapat disimpan dan diambil secara efisien. Sebuah entitas adalah sesuatu yang dapat diidentifikasi dalam lingkungan kerja user, sesuatu yang user ingi telusuri. Sebuah kelas entitas adalah sekumpulan entitas dan digambarkan oleh struktur atau format entitas ${ }^{[20]}$

\section{III.PERANCANGAN SISTEM}

\section{A. Tahap Pengembangan Aplikasi}

Tahapan pengembangan Aplikasi memiliki tujuan untuk men-desain sistem aplikasi baru yang dapat menyelsaikan masalah-masalah yang dihadapi organisasi atau perusahaan. Software Development Live Cycle (SDLC) adalah proses mengembangkan atau mengubah suatu sistem perangkat lunak dengan menggunakan model-model yang digunakan orang untuk mengembangkan sistem-sistem perangkat lunak sebelumnya. Model yang digunakan dalam penelitian perancangan aplikasi UKM Basket Universitas Diponegoro. Model waterfall terdiri dari 5 tahap yaitu Analisis Kebutuhan, Desain, Pengodean, Pengujian dan Pemeliharaan.

\section{B. Analisis Kebutuhan}

Permasalahan merupakan latar belakang untuk membangun sebuah sistem yang baru, seringkali perekayasa perangkat lunak kesulitan dalam menentukan apa saja yang harus dilakukan oleh sistem. Deskripsi layanan dan batasan merupakan kebutuhan bagi sistem dan proses menemukan, menganalisis, mendokumentasikan dan memeriksa layanan dan batasan ini disebut analisis kebutuhan. Analisis kebutuhan ini diperlukan agar sistem dapat mencapai tujuan yang diharapkan.

Analisis sistem yang telah dibuat diharapkan mampu berjalan sesuai dengan keinginan sebagai berikut.

1. Aplikasi mampu menampilkan daftar lapangan yang biasa digunakan untuk latihan

2. Aplikasi dapat menampilkan detil informasi lapangan.

3. Aplikasi mampu menampilkan rute yang akan di tuju pada lapangan berdasarkan lokasi pengguna.

4. Aplikasi mampu menampilkan alarm untuk pengingat jam latihan yang berbunyi satu jam sebelum latihan dimulai dengan menyesuaikan jadwal pada aplikasi.

5. Aplikasi mampu menampilkan fasilitas lain berupa Galeri, Pemain dan Pelatih.

\section{Usecase Diagram}

Usecase merupakan gambaran dari user dengan sistem. Sebuah diagram usecase menggambarkan hubungan antara aktor dan kegiatan yang dilakukan oleh aplikasi.

Pada aplikasi ini melibatkan pengguna dan admin sebagai actor dalam penggunaan sistem, dimana pengguna dapat melihat dan menggunakan aplikasi pada perangkat, seperti melakukan melihat pemain, melihat lokasi lapangan dan melihat jadwal, berita, melihat galeri, melihat profil dan mendapat alarm. Seorang member merupakan pengguna aplikasi yang melakukan pendaftaran member. Sedangkan seorang admin diperlukan untuk mengurus sistem dan mengelola webserver aplikasi, admin mengelola semua kegiatan user yaitu member, pemain, lapangan, jadwal, alarm, berita, galeri, juga yang menentukan apabila user ingin mendaftar untuk memiliki akun dengan cara memverifikasi member. Usecase diagram apliakasi ini dapat dilihat pada Gambar 1. 


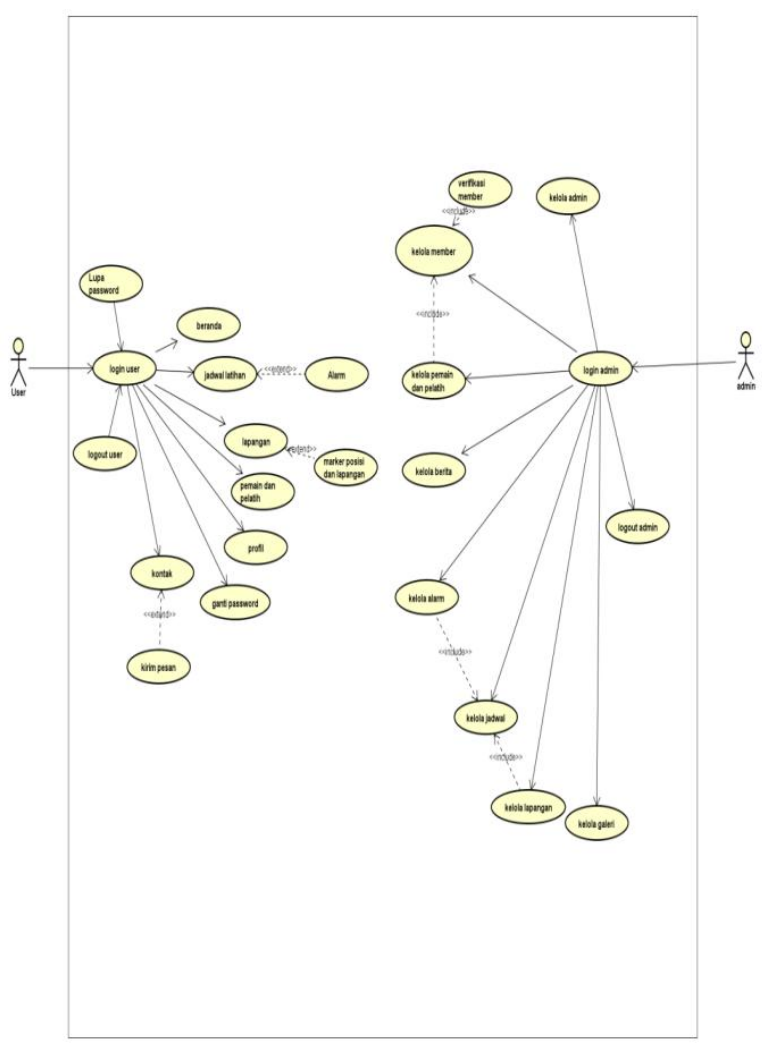

Gambar 1. Usecase Diagram

\section{Activity Diagram}

Activity Diagram menggambarkan berbagai alur aktivitas dalam sistem yang sedang dirancang. Diagram Activity juga dapat menggambarkan proses paralel yang mungkin terjadi pada beberapa eksekusi. Berikut merupakan beberapa diagram aktivitas yang terdapat pada perancangan aplikasi. Diagram aktivitas verifikasi dapat dilihat pada Gambar 2.

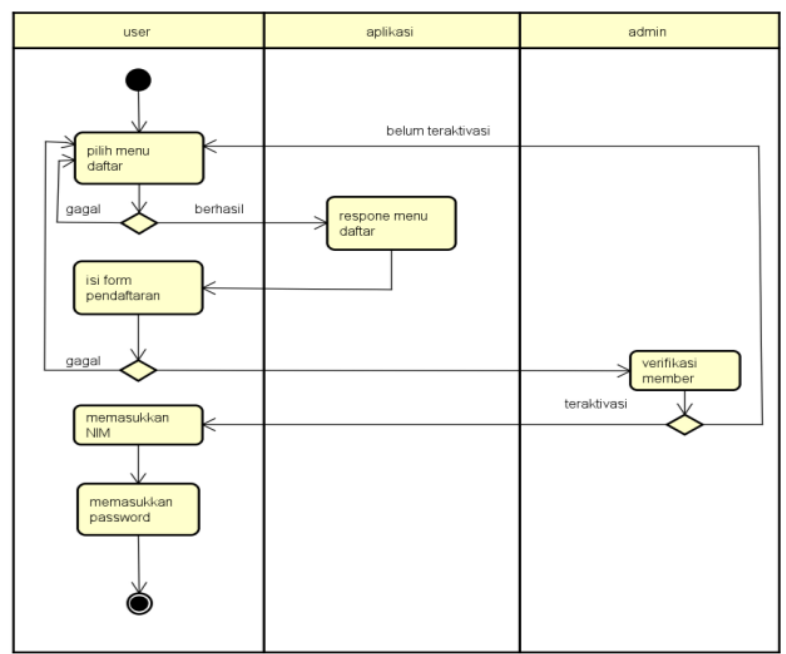

Gambar 2. Activity Diagram Verifikasi

Diagram aktivitas login merupakan suatu proses untuk menampilkan login setelah melakukan verifikasi pada aplikasi UKM Basket Universitas Diponegoro. Pengguna dapat melihat berita setelah log in pada aplikasi. Berita tersebut berisi tentang kejuaraan dan berita terbaru seputar UKM. Diagram aktivitas Login dapat dilihat pada Gambar 3.

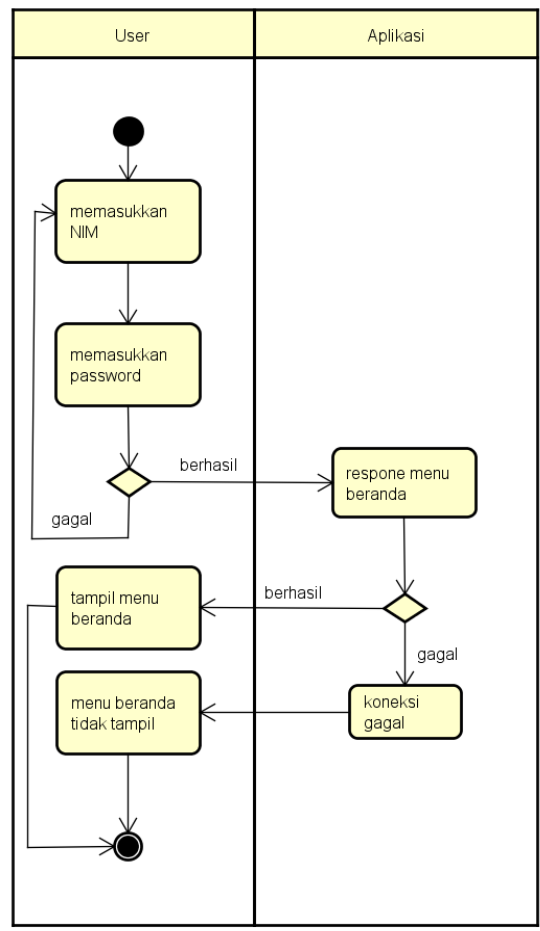

Gambar 3. Activity Diagram Login

Diagram aktivitas jadwal latihan merupakan proses dimana pengguna dapat mengetahui jadwal latihan UKM. Pengguna juga dapat mengaktifkan alarm pada menu jadwal. Sedangkan admin bertugas untuk setting alarm dengan mengubah waktu latihan UKM. Pengguna hanya dapat mengaktifkan alarm pada saat aplikasi dijalankan. Alarm itu sendiri akan berbunyi satu jam sebelum jadwal latihan yang telah ditentukan oleh admin. Gambar 4 merupakan tampilan diagram aktivitas jadwal latihan.

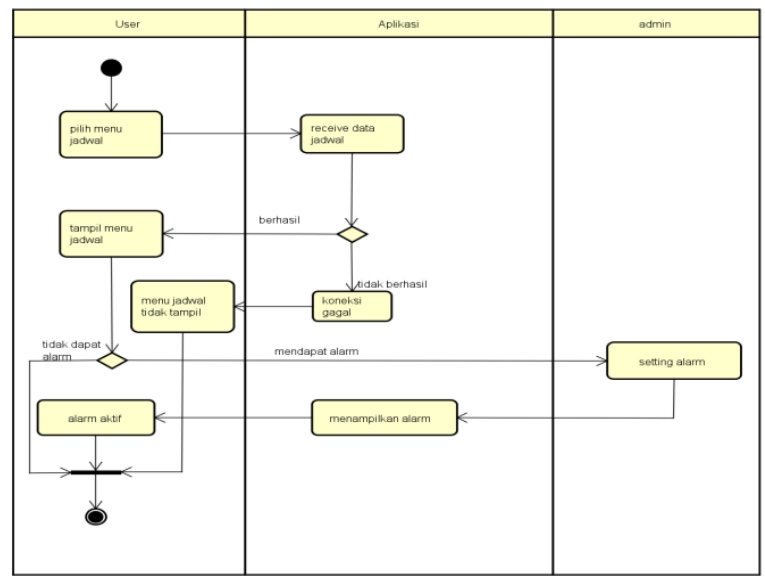

Gambar 4. Activity Diagram Jadwal Latihan

Diagram aktivitas lapangan berfungsi untuk menampilkan daftar lapangan yang biasa dipakai untuk 
latihan UKM. Pengguna dapat melihat daftar lapangan dengan cara memilih menu lapangan pada menu utama. Setelah pengguna memilih menu lapangan maka akan tampil daftar lapangan yang biasa digunakan untuk latihan. Pengguna juga dapat melihat detil lapangan dan posisi lapangan antara user dan lokasi dengan memilih submenu show route. Halaman detail lapangan dan lokasi lapangan akan tampil ketika pengguna memilih submenu show route. Diagram aktivitas lapangan dapat dilihat pada Gambar 5

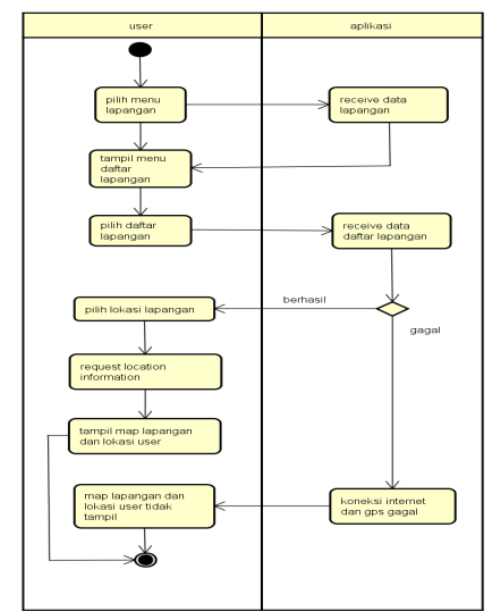

Gambar 5. Activity Diagram Lapangan

\section{E. Class Diagram}

Diagram kelas merupakan struktur statis yang menggambarkan struktur dari suatu sistem dengan menunjukkan sistem kelas, atribut, operasi, dan hubungan antara objek-objek. Pada diagram kelas dapat dilihat di gambar 6.

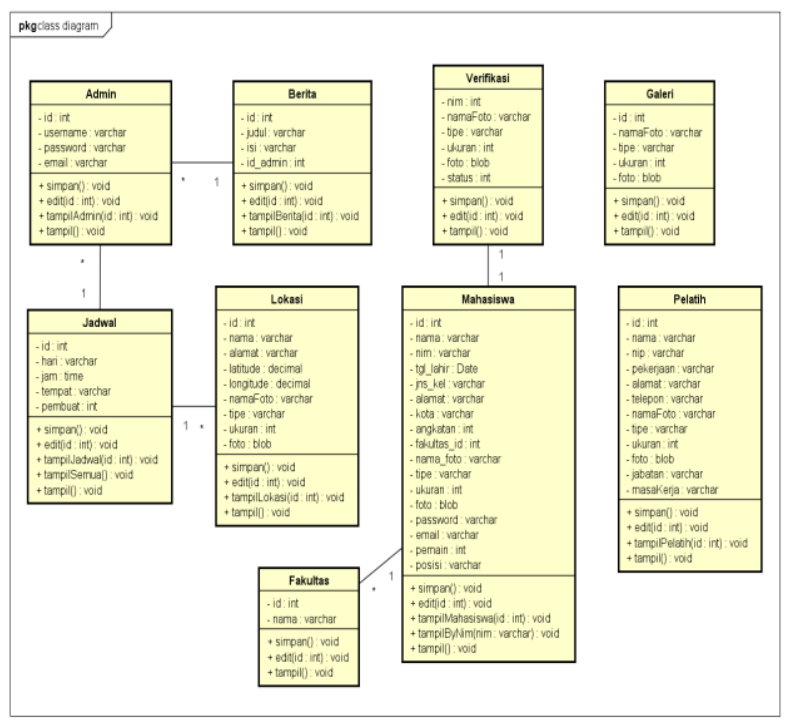

Gambar 6. Class Diagram

\section{A. Impelmentasi Basis Data}

Tahapan ini mengimplementasikan hasil perancangan basis pada sistem yang telah dibuat sebelumnya. Impelmentasi basis data table admin dapat dilihat pada Gambar 7.

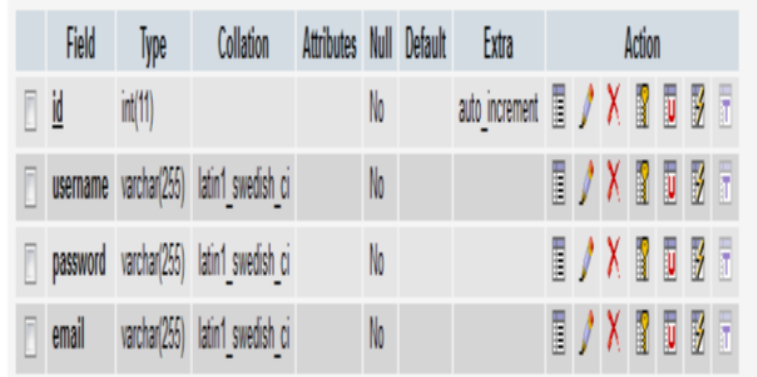

Gambar 7. Struktur Tabel Administrator

Pada Gambar 8 Menampilkan struktur tabel jadwal pada basis data adrian2009 digunakan untuk menyimpan database jadwal latihan pada UKM Basket Universitas Diponegoro. Pada database ini juga tersambung pada alarm pengingat latihan pada aplikasi.

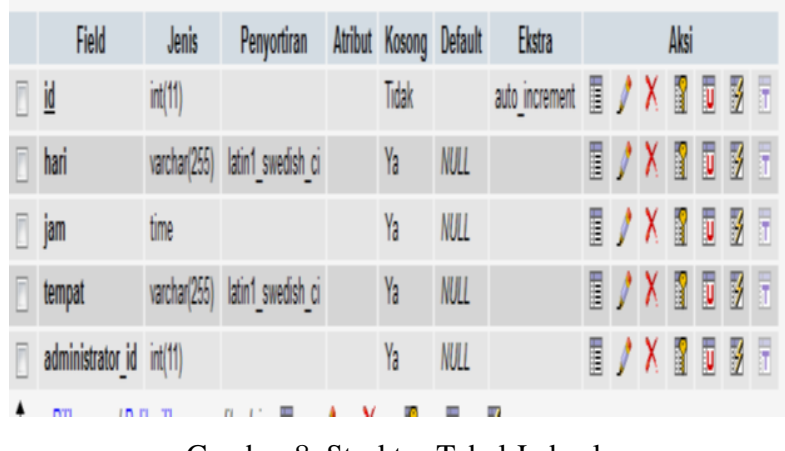

Gambar 8. Struktur Tabel Jadwal

Pada Gambar 9 Menampilkan struktur tabel lokasi yang merupakan tempat menyimpan data - data lokasi lapangan yang ditampilkan pada aplikasi students.siskom-undip.net/ukmbasket, semua data lokasi lapangan yang dimasukkan oleh admin akan tersimpan pada tabel ini, dan ditampilkan pada perangkat bergerak.

\begin{tabular}{|c|c|c|c|c|c|c|c|c|}
\hline & Field & Jenis & Penyotiran & Atribut & Kosong & Default & Ekstra & Aksi \\
\hline [ & id & $\operatorname{in}($ (11) & & & Tidak & & atto increment & 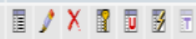 \\
\hline I & nama & larcha|255) & Itint_suedsh_a & & $Y_{a}$ & NUL & & 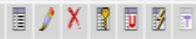 \\
\hline I & alamat & larcha|255) & Itain__suedsh_ai & & $Y_{a}$ & NUL & & 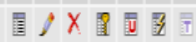 \\
\hline$\overline{1}$ & latitude & decinal|(11,8) & & & $Y_{a}$ & NUL & & 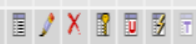 \\
\hline [ & longitude & decimal(11,8) & & & $Y_{a}$ & NUL & & 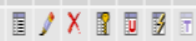 \\
\hline [ & nama gambar & lacha|255) & Ittin1_suedsh_a & & $Y_{a}$ & NUL & & 唯 $\boldsymbol{X}$ X \\
\hline [ & tipe & lacha|255) & latin__suedsh_a & & $Y_{a}$ & NUL & & 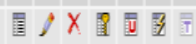 \\
\hline [ & ukuran & int(11) & & & $Y_{a}$ & NULL & & 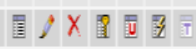 \\
\hline & foto & medunblob & & suer & $Y_{a}$ & NUL & & 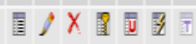 \\
\hline
\end{tabular}

Gambar 9. Struktur Tabel Lokasi

\section{IMPLEMENTASI DAN PENGUJIAN}


Pada Gambar 10 Menampilkan struktur tabel mahasiswa yang merupakan tempat menyimpan data mahasiswa yang mendaftar pada aplikasi UKM Basket. Pada database ini admin dapat memasukkan daftar pemain putra maupun putri pada menu pemain dan pelatih.

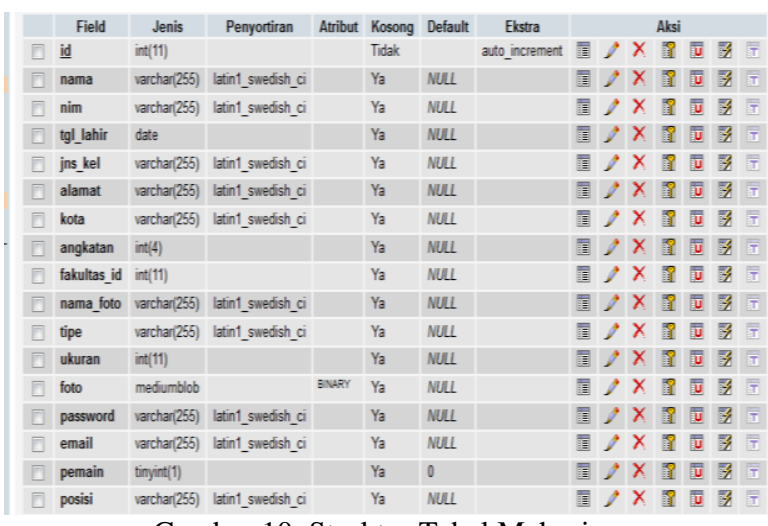

Gambar 10. Struktur Tabel Mahasiswa

Pada Gambar 11 menampilkan struktur tabel verifikasi merupakan database dimana admin memverifikasi member yang mendaftar ke aplikasi. Pada saat pengguna mendaftar, pengguna harus menunggu proses verifikasi yang dilakuka oleh admin. Proses verifikasi diperlukan untuk memastikan member yang bias masuk aplikasi hanya mahasiswa Universitas Diponegoro.

\begin{tabular}{|c|c|c|c|c|c|c|c|c|}
\hline & Field & Jenis & Penyortiran & Atribut & Kosong & Default & Ekstra & Aksi \\
\hline 田 & $\underline{\text { nim }}$ & varchar(255) & latin1_swedish_ci & & Tidak & & & 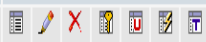 \\
\hline ( & nama_foto & varchar(255) & latin1__wedish__i & & $Y_{a}$ & NULL & & 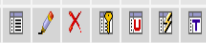 \\
\hline [ & tipe & varchar(255) & latin1__wedish__i & & $Y_{a}$ & NULL & & 四 \\
\hline (] & ukuran & $\operatorname{int}(11)$ & & & $Y_{a}$ & NULL & & 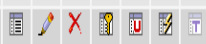 \\
\hline 目 & foto & mediumblob & & BNARY & $\gamma_{a}$ & NULL & & 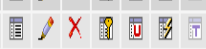 \\
\hline [ & STATUS & tinyin:(1) & & & $\gamma_{a}$ & NULL & & 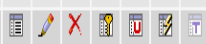 \\
\hline
\end{tabular}

\section{B. Implementasi Antarmuka}

Implementasi desain antarmuka merupakan transformasi desain antarmuka aplikasi. Tampilan antarmuka dari aplikasi Dekostembalang adalah sebagai berikut.

\section{Antarmuka Halaman Login}

Menu Login pada aplikasi UKM Basket merupakan tampilan awal pada program, dimana pada menu log in ini pengguna dapat melakukan tiga proses yaitu log in, daftar, dan lupa password. Pada saat aplikasi dibuka maka yang akan tampil di perangkat bergerak seperti tampilan pada Gambar 12 .

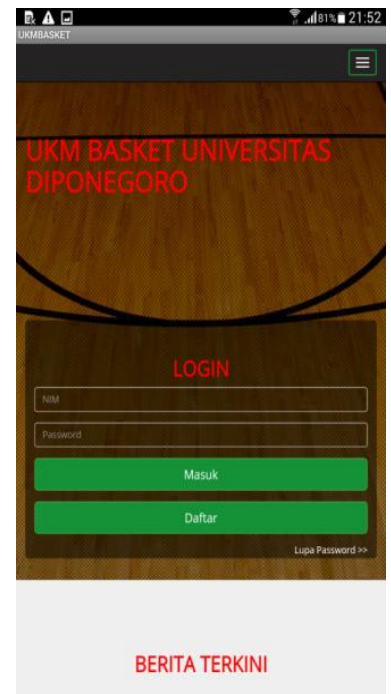

Gambar 12. Halaman Login

\section{Antarmuka Halaman Beranda}

Pada antarmuka menu beranda merupakan tampilan awal ketika pengguna berhasil login dan masuk ke aplikasi. Pada menu beranda terdapat update berita tentang aplikasi UKM Basket Universitas Diponegoro. Implementasi menu beranda dapat dilihat pada Gambar 13

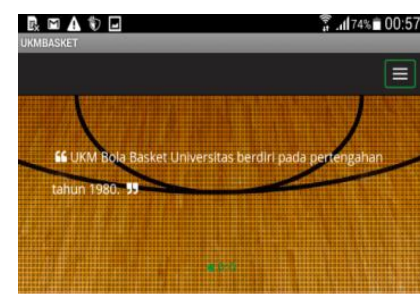

BERITA TERKINI

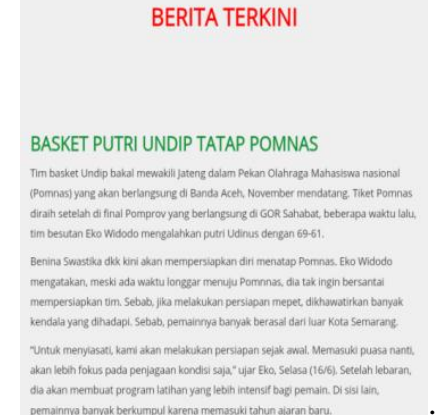

Gambar 13. Halaman Menu Beranda

\section{.3. Antarmuka Halaman Galeri}

Antarmuka menu galeri akan menampilkan galeri foto yang diabadikan oleh UKM Basket Universitas Diponegoro. Untuk tampilan antarmuka menu tgaleridapat dilihat pada Gambar 14. 


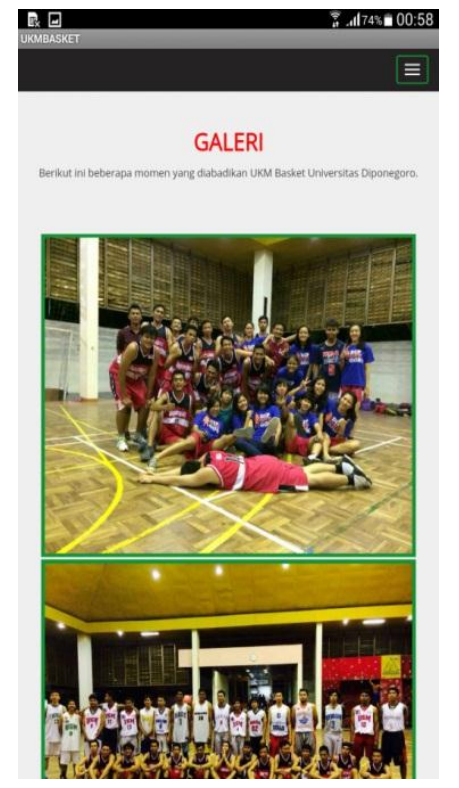

Gambar 14. Halaman Menu Terdekat

\section{Antarmuka Halaman Jadwal Latihan}

Pada Antarmuka menu jadwal menampilkan jadwal latihan UKM Basket Universitas Diponegoro, perancangan antarmuka jadwal latihan dapat dilihat pada Gambar 15.
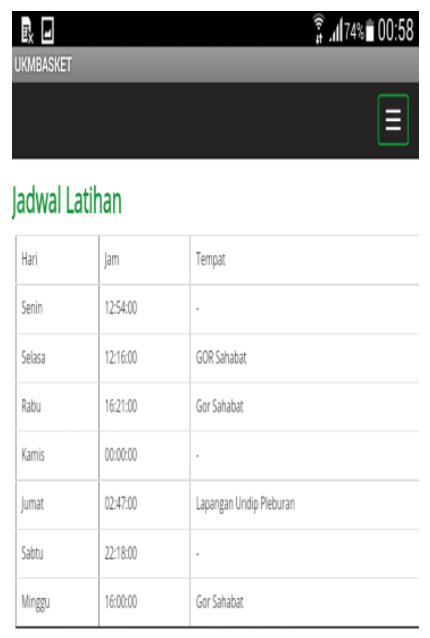

$02015 \mid$ by bition putrenda

Gambar 15. Halaman Menu Detil Gallery Kos

Di dalam menu jadwal latihan ini juga tersambung pada alarm pengingat jam latihan. Alarm akan menyesuaikan jadwal latihan setelah aplikasi dibuka. Alarm pengingat akan berbunyi satu jam sebelum latihan dimulai. Perancangan antarmuka alarm dapat dilihat pada gambar 16 .

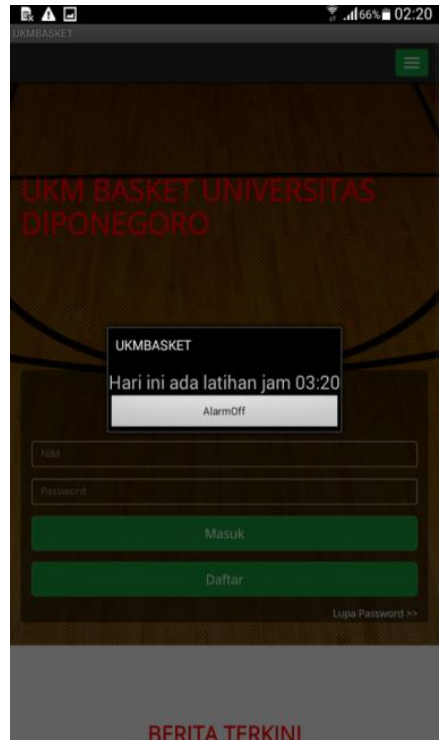

Gambar 16. Tampilan Alarm

\section{Antarmuka Halaman Lapangan}

Pada menu lapangan merupakan menu yang menampilkan informasi lapangan yang biasa dipakai latihan UKM Basket Universitas Diponegoro. Antarmuka mепи lapangan dapat dilihat pada Gambar 17.

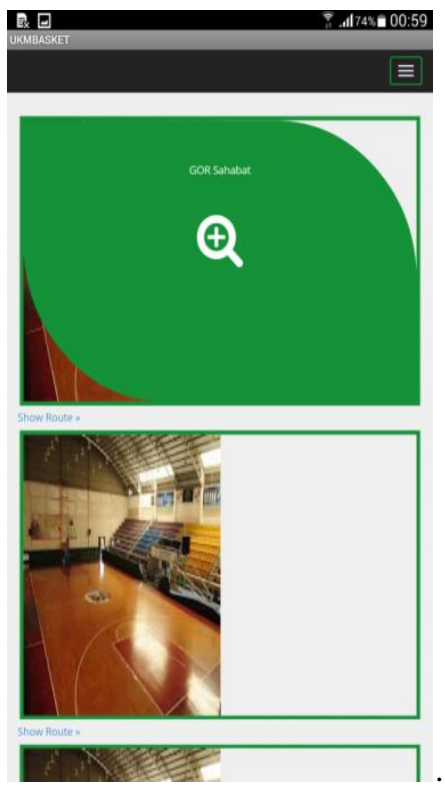

Gambar 17. Halaman Menu Lapangan

Pada menu lapangan terdapat menu show route yang berfungsi untuk menampilkan alamat lapangan dan peta lokasi lapangan serta menunjukkan rute untuk posisi user dan lokasi lapangan. Perancangan antarmuka show route dapat dilihat pada gambar 18 . 


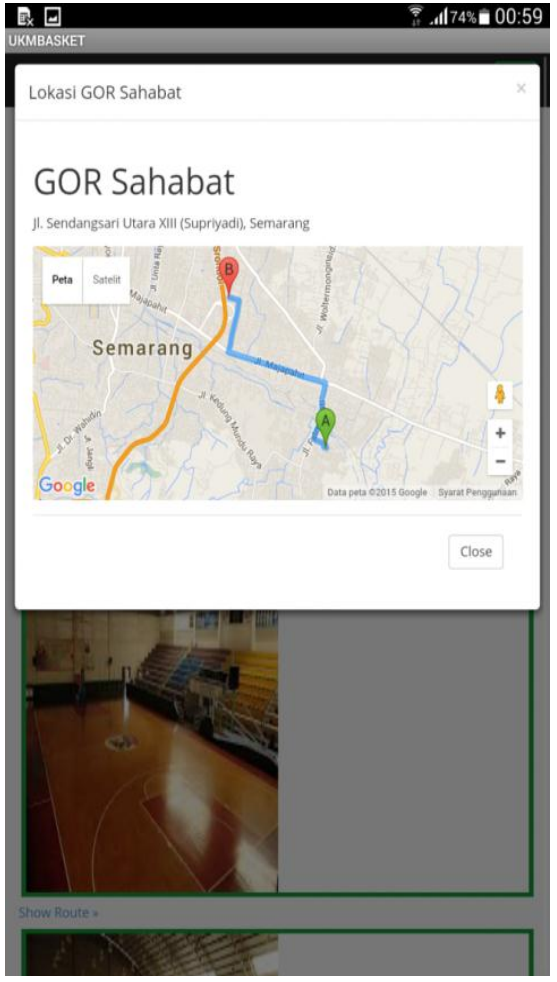

Gambar 18. Tampilan Show Route

6. Antarmuka Halaman Profil

Menu profil menampilkan deskripsi pengguna itu sendiri. Data yang berada pada halaman profil ditampilkan sama seperti pengguna mendaftar pada aplikasi UKM Basket. Dimana mеnи profil ditunjukan pada Gambar 19
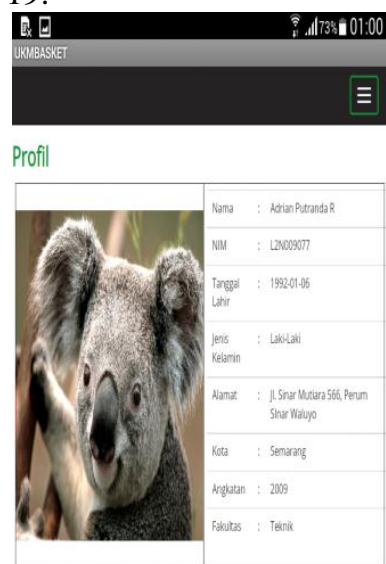

Q 2015 | by Adrian Putranda

Gambar 19. Halaman Menu Profil

7. Antarmuka Halaman Kontak Pengelola

Tampilan mеnи kontak pengelola dapat di lihat pada Gambar 20.

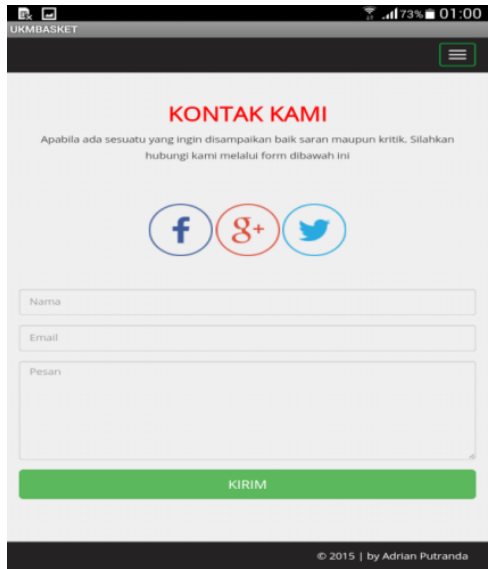

Gambar 20. Halaman Menu Kontak Pengelola

\section{Antarmuka Halaman Admin}

Halaman Admin pada UKM Basket merupakan halaman bagi pengelola aplikasi untuk memasukkan data, mengubah data maupun menghapus data yang akan di tampilkan pada halaman aplikasi UKM Basket. Halaman login Admin dapat dilihat pada Gambar 21.

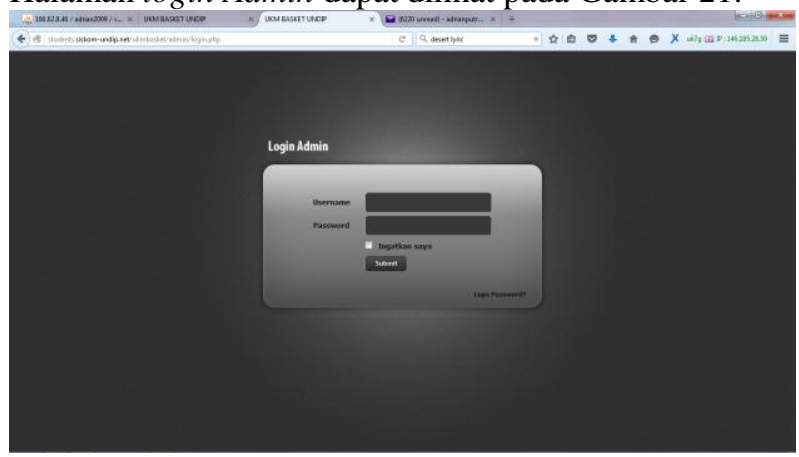

Gambar 21. Halaman Menu Login Admin

\section{Pengujian}

Pada aplikasi dekostembalang pengujian dengan metode blackbox di fokuskan pada keperluan fungsional dari software yang berusaha untuk menemukan kesalahan dalam beberapa kesalahan seperti fungsi aplikasi salah, kesalahan interface, kesalahan struktur data atau akses basisdata, kesalahan kinerja. Hasil pengujian dapat dilihat pada Tabel 4.1

Tabel 4.1 Pengujian Black-box
\begin{tabular}{|c|c|c|c|}
\hline $\begin{array}{c}\text { Nama } \\
\text { Pengujian }\end{array}$ & $\begin{array}{c}\text { Bentuk } \\
\text { Pengujian }\end{array}$ & $\begin{array}{c}\text { Hasil Yang } \\
\text { Diharapkan }\end{array}$ & Hasil \\
\hline $\begin{array}{c}\text { Pengujian } \\
\text { aplikasi } \\
\text { UKMBASKE } \\
\text { T.apk }\end{array}$ & $\begin{array}{c}\text { Mengklik } \\
\text { aplikasi } \\
\text { UKMBASKET } \\
\text { pada perangkat } \\
\text { bergerak }\end{array}$ & $\begin{array}{c}\text { Muncul tampilan } \\
\text { login dari } \\
\text { UKMBASKET }\end{array}$ & Berhasil \\
\hline Penguijan & $\begin{array}{c}\text { Mengklik menu } \\
\text { posisiku }\end{array}$ & $\begin{array}{c}\text { Muncul tampilan } \\
\text { menu posisiku } \\
\text { beserta map dan } \\
\text { menu daftar } \\
\end{array}$ & Ber posisi \\
penguna & Berhasil \\
\hline
\end{tabular}




\begin{tabular}{|c|c|c|c|}
\hline $\begin{array}{l}\text { Pengujian } \\
\text { menu lupa } \\
\text { Password }\end{array}$ & $\begin{array}{l}\text { Mengklik menu } \\
\text { lupa password }\end{array}$ & $\begin{array}{c}\text { Muncul tampilan } \\
\text { masukkan NIM } \\
\text { dan email }\end{array}$ & Berhasil \\
\hline $\begin{array}{l}\text { Pengujian } \\
\text { menu beranda }\end{array}$ & $\begin{array}{l}\text { Log in pada } \\
\text { aplikasi } \\
\text { UKMBASKET }\end{array}$ & $\begin{array}{l}\text { Muncul tampilan } \\
\text { awal aplikasi } \\
\text { berupa berita } \\
\text { terkini }\end{array}$ & Berhasil \\
\hline $\begin{array}{l}\text { Pengujian } \\
\text { menu galeri }\end{array}$ & $\begin{array}{l}\text { Mengklik menu } \\
\text { galeri }\end{array}$ & $\begin{array}{l}\text { Muncul tampilan } \\
\text { daftar foto galeri }\end{array}$ & Berhasil \\
\hline $\begin{array}{l}\text { Pengujian } \\
\text { menu jadwal } \\
\text { latihan }\end{array}$ & $\begin{array}{l}\text { Mengklik menu } \\
\text { jadwal latihan }\end{array}$ & $\begin{array}{l}\text { Muncul tampilan } \\
\text { jadwal latihan } \\
\text { UKM Basket } \\
\text { Universitas } \\
\text { Diponegoro }\end{array}$ & Berhasil \\
\hline $\begin{array}{l}\text { Pengujian } \\
\text { alarm }\end{array}$ & $\begin{array}{l}\text { Masuk ke } \\
\text { aplikasi untuk } \\
\text { menyesuaikan } \\
\text { jam perangkat } \\
\text { bergerak }\end{array}$ & $\begin{array}{l}\text { Alarm tampil } \\
\text { berupa nada } \\
\text { dering dan } \\
\text { notifikasi }\end{array}$ & Berhasil \\
\hline $\begin{array}{l}\text { Pengujian } \\
\text { menu } \\
\text { lapangan }\end{array}$ & $\begin{array}{l}\text { Mengklik menu } \\
\text { lapangan }\end{array}$ & $\begin{array}{l}\text { Tampil daftar } \\
\text { lapangan }\end{array}$ & Berhasil \\
\hline $\begin{array}{l}\text { Pengujian } \\
\text { menu show } \\
\text { route }\end{array}$ & $\begin{array}{l}\text { Mengklik menu } \\
\text { show route }\end{array}$ & $\begin{array}{l}\text { Muncul tampilan } \\
\text { map beserta rute } \\
\text { antara pengguna } \\
\text { dan lokasi }\end{array}$ & berhasil \\
\hline $\begin{array}{l}\text { Pengujian } \\
\text { menu profil }\end{array}$ & $\begin{array}{l}\text { Mengklik menu } \\
\text { profil }\end{array}$ & $\begin{array}{l}\text { Muncul tampilan } \\
\text { tentang profil } \\
\text { pengguna }\end{array}$ & Berhasil \\
\hline $\begin{array}{l}\text { Pengujian } \\
\text { menu ganti } \\
\text { password }\end{array}$ & $\begin{array}{l}\text { Mengklik menu } \\
\text { ganti password }\end{array}$ & $\begin{array}{l}\text { Muncul tampilan } \\
\text { ganti password }\end{array}$ & Berhasil \\
\hline $\begin{array}{l}\text { Pengujian } \\
\text { menu kontak }\end{array}$ & $\begin{array}{l}\text { Mengklik menu } \\
\text { kontak }\end{array}$ & $\begin{array}{l}\text { Muncul tampilan } \\
\text { menu kontak } \\
\text { pengelola beserta } \\
\text { form pengisian } \\
\text { pesan }\end{array}$ & Berhasil \\
\hline $\begin{array}{l}\text { Pengujian } \\
\text { menu } \\
\text { verifikasi }\end{array}$ & $\begin{array}{l}\text { Log in pada } \\
\text { halam admin }\end{array}$ & $\begin{array}{l}\text { Checklist pada } \\
\text { tabel verifikasi }\end{array}$ & Berhasil \\
\hline
\end{tabular}

1. Aplikasi dapat mempermudah pengguna menemukan informasi tentang UKM Basket Universitas Diponegoro

2. Aplikasi pencarian lokasi lapangan menggunakan fitur Google Map APIs dalam pembuatan fungsi navigasi peta dan posisi.

3. Fungsi Global Positioning System (GPS) pada perangkat bergerak berperan penting dalam menentukan keakuratan posisi dari pengguna dan lokasi lapangan yang dituju.

4. Aplikasi telah dilengkapi dengan Javascript Object Notation (JSON) dan Alert Dialog sehingga mempermudah pengguna mengingat jam latihan dengan adanya alarm pengingat latihan yang berfungsi satu jam sebelum latihan dimulai.

B. Saran

Saran yang dapat diambil dari penelitian yang terlah dilakukan pada perancangan Aplikasi UKM Basket adalah sebagai berikut.

1. Perlu dilakukan penelitian lanjutan untuk mengembangkan aplikasi UKM Basket Universitas Diponegoro pada perangkat bergerak selain Android.

2. Penambahan fitur pada Aplikasi UKMBASKET masih sangat disarankan, seperti penambahan jadwal pada fakultas dan jurusan agar mencakup semua lingkungan Universitas.

3. Perlu dilakukan penelitian lebih lanjut bagaimana membuat agar Aplikasi UKM Basket dapat dijalan di sistem operasi seperti Blackberry, IOS dan Windows phone.

\section{DAFTAR PUSTAKA}

[1] Agus Sucista, "Pembangunan Sistem Aplikasi Layanan Berbasis Lokasi Pencarian ATM dan Pom Bensin Terdekat Berbasis Android", Sekolah Tinggi Manajemen Informatika dan Komputer, Amikom, Yogyakarta, 2012.

[2] Irawan, Yudi. 2011. Perancangan Sistem Informasi Perpustakaan Berbasis Web Application.

[3] Indonesia, BOC. "Pengertian Website, Web Hosting dan Domain Name". 26 November 2007. http://www.boc.web.id/pengertian-website-webhostingdomainname/

[4] SEBI, STEI. "Konsep Dasar SIA". 25 September 2014 https://sebiindonesia.wordpress.com/2014/09/25/konsepsistem-informasi-akuntansi-definisi-dan-bentuk-umum/

[5] Ladjamudin, Al Bahra Bin. 2007, Analisis dan Desain Sistem Informasi, Penerbit Graha Ilmu

[6] Eclipse software, http://en.wikipedia.org/wiki/Eclipse_(software), $\quad 29$ January 2014, (29January 2014).

[7] Google Developers, 2014, Google Maps JavaScript Api V3. [Diakses Tanggal 28 Januari 2014]. http://developers.google.com/maps/documentation/javascri $\mathrm{pt} /$

[8] Google Maps API, http://library.binus.ac.id/eColls/eThesisdoc/Bab2HTML/20 12100267ifbab2/page31.html, 29 January $2014 \quad$ (29 January 2014)

[9] Ashkaf, Arif. "Pengertian Infomasi dan Pebedaan antara Data dengan Informasi". 14 Oktober 2015. https://arifashkaf.wordpress.com/2015/10/14/pengertianinfomasi-dan-pebedaan-antara-data-dengan-informasi/

[10] I Gusti Putu Deviara Putra, "Perancangan Simulasi Sistem Informasi Transportasi Bus Trans Sarbagita 
Dengan Menggunakan Metode Location Basec Service Berbasis Mobile”, Ilmu Komputer Universitas Udayana, Bali, 2014.

[11] Java, http://id.wikipedia.org/wiki/Java, 29 January 2014, (29 January 2014)

[12] JSON, 2006, Pengenalan JSON. [Diakses tanggal 15 Febuary 2014]. http://www.json.org/

[13] Kadir, Abdul.,Dasar Pemrograman Web Dinamis Menggunakan PHP, CV. Andi Offset., Yogyakarta, 2008.

[14] Kadir, Abdul, Mastering AJAX dan PHP. CV. Andi Offset, Yogyakarta,2009.

[15] Suindarti, Game Edukasi Meningkatkan Daya Ingat Anak "Bermain Bersama Dido" dengan Macromedia Director Skripsi Jurusan Sistem Informasi, Sekolah Tinggi Manajemen Informatika dan Komputer Amikom Yogyakarta, 2011. Nazruddin, Safaat, Aplikasi Berbasis Android, Informatika. Bandung, 2013.
[16] Binus. "SPORTS : UKM BASKET". 13 Juni 2013. http://web.binus.ac.id/SCDC/StudentActivityUnit/Student ActivityUnit.aspx?id=BASKET

[17] H, Nazruddin Safaat, Pemrograman Aplikasi Mobile Smartphone dan Tablet PC Berbasis Android, Informatika, Bandung, 2012.

[18] Bunafit, Nugroho, Membuat Sistem Informasi Penjualan Berbasis WEB dengan PHP dan MySQL, Gava Media Yogyakarta, 2007.

[19] Bunafit, Nugroho, Pengolahan Database dengan MySQL. CV Andi. Yogyakarta, 2004.

[20] Setiawan, Aris Migi. "Pengertian Waterfall dan Jenis UML”. $\quad 25 \quad$ September 2012. http://arismigisetiawan.blogspit.com/pengertian-waterfall 